\title{
PERANAN PANTI ASUHAN PUTRI MUHAMMADIYAH KOTA PROBOLINGGO DALAM MENUMBUHKAN NILAI-NILAI KARAKTER
}

\author{
Deniarika Alifiani Maula, Nurul Zuriah, Rohmad Widodo \\ FKIP Universitas Muhammadiyah Malang, Indonesia \\ Email: deniarika.alifiani@gmail.com
}

\begin{abstract}
ABSTRAK
Penelitian ini bertujuan untuk mendeskripsikan (1) peranan panti asuhan putri Muhammadiyah Kota Probolinggo dalam menumbuhkan nilai-nilai karakter; (2) faktor pendukung dan penghambat; dan (3) solusi untuk mengatasi hambatan yang muncul. Fokus pada penelitian ini adalah nilai-nilai karakter religius dan mandiri. Penelitian ini menggunakan jenis penelitian kualitatif dan pendekatan deskriptif. Tempat penelitian yakni di Panti Asuhan Putri Muhammadiyah Kota Probolinggo. Prosedur penelitian terdiri dari tahapan pra penelitian, pelaksanaan, dan analisis data. Teknik pengumpulan data menggunakan observasi, wawancara, dan dokumentasi. Teknik analis data terdiri dari empat alur kegiatan yaitu pengumpulan data, reduksi data, penyajian data dan penarikan kesimpulan. Teknik keabsahan data menggunakan triangulasi sumber. Hasil penelitian menunjukkan bahwa (1) berprinsip pada rujukan, pedoman, dan acuan Pimpinan Daerah Muhammadiyah. Anak diberikan kegiatan yang beragam setiap harinya mulai dari subuh sampai malam. (2) Faktor pendukung yakni keuangan panti, keterlibatan pengurus panti yang maksimal, fasilitas sarana dan prasarana, dan kegiatan anak. Faktor penghambat yakni sumber daya manusia minim, karakter anak, anak pernah pulang malam, kesenjangan, keadaan anak, dan kegiatan lain diluar panti. (3) Solusi mengatasi hambatan yang muncul yakni diperlukan SDM yang kompeten, selalu sabar menghadapi anak, pembinaan anak, memotivasi anak, bertatap muka, dan diistiqomahkan.
\end{abstract}

Kata kunci: Nilai Karakter; Panti Asuhan

\section{ABTRACT}

This study aims to describe (1) the role of the Muhammadiyah City of Probolinggo orphanage in fostering character values; (2) supporting and inhibiting factors; and (3) solutions to overcome the obstacles that arise. The focus of this research is the values of religious and independent characters. This study uses a type of qualitative research and descriptive approach. The place of research is at the Putri Muhammadiyah Orphanage in Probolinggo City. The research procedure consists of the stages of pre-research, implementation, and data analysis. The technique of collecting data uses observation, interviews, and documentation. Data analysis techniques consist of four activity lines, namely data collection, data reduction, data presentation and conclusion drawing. The data validity technique uses source triangulation. The results of the study show that (1) principled the references, guidelines, and references of the Muhammadiyah Regional Leaders. Children are given various activities every day from dawn to night. (2) Supporting factors, namely the institution's finances, the involvement of the maximum nursing staff, facilities and infrastructure, and children's activities. Inhibiting factors are minimal human resources, character of children, children who have come home late at night, gaps, conditions of children, and other activities outside the institution. (3) Solutions to overcome the obstacles that arise that are required competent human resources, always patient with children, fostering children, motivating children, face to face, and blessed.

Keywords: Character Value; Orphanages 


\section{PENDAHULUAN}

Anak sebagai karunia Tuhan harus dijaga, dirawat, dan di didik agar mampu menghadapi tantangan masa depan. Untuk itu, anak harus mendapatkan kesempatan yang seluas-luasnya untuk tumbuh dan berkembang secara optimal, baik fisik, mental, maupun sosial.

Agar mampu memikul tanggung jawab tersebut dengan cara memberikan pendidikan, baik melalui pendidikan formal, pendidikan non formal, maupun pendidikan informal. Dengan demikian, anak perlu diperhatikan dengan sungguhsungguh.

Pendidikan yang dituangkan dalam Undang-Undang Republik Indonesia Nomor 20 tahun 2003 pasal 3 menyatakan bahwa, pendidikan nasional berfungsi mengembangkan kemampuan dan membentu watak serta peradaban bangsa yang bermartabat dalam rangka mencerdaskan kehidupan bangsa, yang bertujuan untuk berkembangnya potensi peserta didik agar menjadi manusia yang bertaqwa dan beriman kepada Tuhan Yang Maha Esa, berakhlak mulia, sehat berilmu, cakap, kreatif, mandiri, dan menjadi warga negara yang demokratis serta bertanggung jawab. Tujuan pendidikan nasional dapat terwujud melalui pendidikan karakter. (Undang-Undang Republik Indonesia Nomor 20 Tahun 2003:3)

Pendidikan karakter sangatlah penting bagi anak, kalangan pelajar atau lembaga pendidikan formal untuk membentuk generasi yang berkualitas. Dikarenakan, pendidikan karakter sebagai pondasi bangsa yang sangat penting dimiliki dan perlu ditanamkan sejak dini kepada anak.

Undang-Undang Dasar Republik Indonesia tahun 1945 pasal 34 ayat (1) yang berbunyi "fakir miskin dan anakanak terlantar di pelihara oleh negara". Berdasarkan ketentuan di atas, pemerintah membuat tempat untuk menampung anak- anak terlantar yang disebut dengan panti asuhan.

Panti Asuhan sebagai penyelenggara program pendidikan mempunyai tanggung jawab untuk menumbuhkan nilai-nilai karakter pada anak. Dalam panti asuhan anak di didik dan dibina. Dengan demikian, anak akan mengalami proses internalisasi, pembiasaan, dan akhirnya menjadi bagian dari hidupnya sehingga karakter anak terbentuk. Hal tersebut sangat penting karena bertujuan untuk mengarahkan anak agar terwujudnya generasi yang berkualitas.

Panti Asuhan Putri Muhammadiyah Kota Probolinggo sebagai tempat untuk mengantarkan anak asuh membentuk karakter yang beriman dan berakhlak mulia, cerdas, kreatif, inovatif, mandiri serta mampu menjadi da'i bagi diri sendiri, persyarikatan, agama, umat, dan agama. Pembentukan karakter anak sangat penting agar anak dapat menjadi manusia yang memiliki karakter sesuai dengan falsafat bangsa Indonesia yakni Pancasila. Dengan demikian, panti asuhan Putri Muhammadiyah Kota Probolinggo memiliki peranan dan tanggungjawab untuk mewujudkan karakter anak sesuai dengan visi penyelenggara panti asuhan.

Seiring berkembangan ilmu, teknologi, komunikasi, dan arus globalisasi membawa dampak perubahan pada berbagai aspek kehidupan tak terkecuali dalam bidang pendidikan. Permasalahan saat ini yang ditemui karakter anak asuh agak memudar sehingga perlu adanya dorongan untuk menguatkan kembali penumbuhan karakter pada anak.

Melihat permasalahan di atas, peranan panti asuhan dalam menumbuhkan nilainilai karakter perlu dimaksimalkan kembali agar dapat membina dan mengarahkan anak. Langkah ini diharapkan dapat menjadi bagian dari proses pembentukan karakter generasi bangsa sehingga tercipta generasi yang berkarakter. 
Peranan merupakan bagian dinamis dalam suatu kedudukan (status). Seseorang yang melaksanakan suatuhak dankewajiban sesuai dengan kedudukannya artinya menjalankan suatu peranan. Peranan dan kedudukan tidak dapat dipisahkan, karena saling bergantung satu sama lain. Tidak ada peranan tanpa kedudukan atau kedudukan tanpa peranan (Soekanto, 2015:210).

Peraturan Menteri Sosial Republik Indonesia Tahun 2009 Pasal 24 tentang Organisasi dan Tata Kerja Panti Sosial di Lingkungan Departemen Sosial (2009:8), menjelaskan panti sosial asuhan anak mempunyai tugas memberikan bimbingan, pelayanan dan rehabilitasi sosial yang bersifat kuratif, rehabilitatif, promotif dalam bentuk bimbingan pengetahuan dasar pendidikan, fisik, mental, sosial, pelatihan keterampilan, resosialisasi bimbingan lanjut bagi anak yatim, piatu dan yatim piatu yang kurang mampu, terlantar agar potensi dan kapasitas belajarnya pulih kembali, dapat berkembang secara wajar serta pengkajian, pengembangan standar pelayanan dan rujukan.

Menurut Sobri

(2017:8), menumbuhkan dalam diri siswa menjadi sebuah keutamaan dan tujuan utama agar menjadi pembelajaran yang baik. Karena menjadi visi utama dalam sebuah program pendidikan. Serta mengembangkan keutamaan akademis secara utuh harus lebih dipahami.

Suyadi (2013:82), menjelaskan "character so conceived had three interrelated parts: moral knowing; moral feeling, dan moral behavior". Karakter mulia (good character) meliputi serangkaian pengetahuan tentang kebaikan (moral knowing) yang menimbulkan komitmen terhadap suatu kebaikan (moral feeling), dan akhirnya benar-benar melakukan suatu kebaikan (moral behaviour). Dengan demikian karakter mengacu pada serangkaian pengetahuan (cognitives), sikap (attitudes), dan motivasi (motivations), serta perilaku (behaviors) dan keterampilan.

Penguatan karakter penerus bangsa dapat diwujudkan melalui gerakan Penguatan Pendidikan Karakter (PPK) digulirkan sejak tahun 2016 yang menjadi salah satu program prioritas dalam nawacita. Berikut ini nilai utama Gerakan PPK (Penguatan Pendidikan Karakter). Pertama, Nilai religius, yakni mencerminkan keberimanan terhadap Tuhan yang Maha Esa; Kedua, Nilai nasionalisme, yakni mencerminkan kecintaan terhadap negara dan bangsa; Ketiga, Nilai mandiri, yakni mencerminkan sikap yang tidak mudah tergantung pada orang lain dalam menyelesaikan segala pikiraan, waktu, dan tenaga; Keempat, Nilai gotong royong, yakni mencerminkan tindakan bahu membahu menyelesaikan persoalan bersama dan menghargai semangat kerjasama.

Hendriana dan Jacobus (2016:26), menjelaskan pendidikan karakter bertujuan membentuk bangsa yang kompetitif, tangguh, berakhlak mulia, bermoral, bergotong royong, bertoleran, berjiwa patriotik, berorientasi ilmu pengetahuan dan teknologi, dan berkembang dinamis yang semuanya di wujudkan oleh takwa dan iman kepada Tuhan Yang Esa berdasarkan pancasila.

\section{METODE}

Penelitian ini menggunakan jenis penelitian kualitatif dan pendekatan deskriptif. Menurut Moleong (2014:6), penelitian kualitatif adalah penelitian yang bertujuan untuk memahami suatu fenomena yang meliputi tindakan, motivasi, perilaku, persepsi, dan lain-lain yang dialami oleh subjek penelitian yang secara holistik menggunakan bahasa pada satu konteks khusus yang alamiah. Moleong (2014:4), menjelaskan pendekatan deskriptif adalah pendekatan penelitian yang bertujuan untuk mendeskripsikan suatu peristiwa, kejadian, atau gejala yang terjadi saat sekarang.

Penelitian dilaksanakan bulan Februari s/d Maret 2019 di Panti Asuhan Putri 
Muhammadiyah Kota Probolinggo. Subjek penelitian yakni (1) Pimpinan Daerah Muhammadiyah Kota Probolinggo; (2) Kepala Panti Asuhan Putri Muhammadiyah Kota Probolinggo; (3) Pengasuh Panti Asuhan Putri Muhammadiyah Kota Probolinggo; (4) dan Anak asuh Panti Asuhan Putri Muhammadiyah Kota Probolinggo.

Prosedur penelitian yang terdiri dari tahap yakni (1) pra penelitian yakni penulis menyusun rencana penelitian terlebih dahulu yang terurai dalam proposal penelitian. (2) pelaksanaan penelitian yakni melakukan pengumpulan data dalam bentuk observasi, wawancara, dokumentasi, dan studi literatur untuk memperoleh data dan informasi yang diperlukan dalam penelitian. (3) analisis data yakni analisis atas data yang telah diperoleh melalui hasil wawancara, observasi, dan dokumentasi.

Teknik pengumpulan data menggunakan (1) observasi, yakni pengumpulan data yang dimana dilakukan dengan cara pencatatan secara sistematis dan dengan mengadakan penelitian secara teliti. (2) wawancara, Menurut Moleong (2014:186), wawancara adalah percakapan dilakukan oleh dua pihak yakni pewawancaraa (interviewer) yang mengajukan pertanyaan dan terwawancara (interviewe) yang memberikan jawaban atas pertanyaan; (3) dokumentasi, menurut Sukmadinata (2008:221), merupakan suatu teknik pengumpulan data dengan cara menganalisis dan menghimpun dokumen yang meliputi dokumen gambar, elektronik, maupun tertulis.

Teknikanalisisdataterdiridaritahapan pengumpulan data, reduksi data, penyajian data, penarikan kesimpulan. Teknik keabsahan data menggunakan triangulasi sumber yakni yakni membandingkan dan mengecek balik derajat kepercayaan suatu informasi yang diperoleh melalui alat dan waktu yang berbeda, Patton (dalam Moleong, 2014:330).

\section{HASIL DAN PEMBAHASAN \\ Peranan Panti Asuhan Putri Muhammadiyah Kota Probolinggo dalam menumbuhkan nilai- nilai karakter}

Berdasarkan hasil penelitian dan data yang telah dijelaskan pada pembahasan sebelumnnya, dapat dikatakan bahwa panti sosial asuhan anak panti asuhan putri Muhammadiyah Kota Probolinggo menurut Peraturan Menteri Sosial Republik Indonesia Tahun 2009 Pasal 24 tentang Organisasi dan Tata Kerja Panti Sosial di Lingkungan Departemen Sosial (2009:8) sesuai dalam menjalankan tugasnya sebagai berikut :

a. Memberikan bimbingan kepada anak asuh

Membimbing anak menjadi suatu keharusan bagi orangtua, maupun orangtua pengganti. Dengan adanya bimbingan anak akan menjadi terarah sehingga anak memiliki karaker yang baik. Panti asuhan putri Muhammadiyah Kota Probolinggo dalam ini selalu membimbing anak setiap hari seperti selalu di nasehati, mewajibkan anak untuk melaksanakan sholat wajib berjamaah dan membaca alqur'an, selalu membimbing anak agar selalu bersifat baik kepada orang-orang yang disekitarnya, saling berbagi, hidup rukun dan damai, mencintai lingkungan, dan dibekali ilmu pengetahuan seperti al-hadist, tamyiz, qiro'ah, tafsir Alqur'an, kajian aisiyah, hafalan surat Alqur'an, bahasa arab.

b. Memberikan pelayanan

Pelayanan merupakan suatu bentuk prosedur, metode, dan sistem tertentu diberikan kepada orang lain. Sehingga kebutuhan tersebut dapat terpenuhi sesuai dengan harapann atauu keinginann(Kasmir, 2010:22). Memberikan pelayanan bertujuan agar terciptanya suasana panti asuhan yang menyenangkan dan nyaman. Anak panti asuhan putri Muhammadiyah 
Kota Probolinggo diberikan pelayanan maksimal seperti adanya diberikan pelayanan fasilitas yang memadai guna memperlancar proses belajar. Terdapat komputer, sound, ruang kegiatan anak, ruang makan, dapur yang luas, kamar tidur yang besar yakni terdapat empat kamar tidur, serta kamar mandi yang bersih.

c. Pendidikan

Menurut Undang-Undang Republik Indonesia Nomor 20 tahun 2003 pasal 3 tentang sistem pendidikan nasional menyatakan bahwa pendidikan nasional berfungsi mengembangkan kemampuan dan membentuk watak serta peradaban bangsa yang bermartabat dalam rangka mencerdaskan kehidupan bangsa. Anak asuh panti asuhan putri Muhammadiyah Kota Probolinggo diberikan pendidikan di sekolah agar mereka mampu mengejar apa yang diinginkan dan dicapai.

d. Kreativitas

Kreativitas adalah kemampuan umum untuk menciptakan suatu yang baru sebagai kemampuan untuk memberikan gagasan-gagasan baru yang dapat diterapkan dalam pemecahan masalah atau sebagai kemampuan untuk melihat hubungan-hubungan baru (Maitbang, 2017:35). Anak asuh panti asuhan putri Muhammadiyah Kota Probolinggo dibekali kreatifitas yakni pembuatan kripik dan seblak yang bertujuan agar anak memiliki jiwa kewirausahaan. Sehingga anak dapat tumbuh dan berkembang secara optimal.

e. Menjamin keselamatan

Anak benar-benar dijaga oleh pihak panti asuhan sehingga tidak terjadi sesuatu hal yang tidak diinginkan.

Faktor pendudukung dan faktor penghambat peranan dalam menumbuhkan nilai-nilai karakter

Berdasarkan hasil data yang telah diperoleh mengungkapkan bahwa, faktor pendukung peranan panti asuhan putri Muhammadiyah Kota Probolinggo dalam menumbuhkan nilai-nilai karakter yakni sebagai berikut :

1. Keuangan panti

Menurut Listiowati (2013:21), keuangan adalah suatu proses kegiatan yang berhubungan dengan uang atau dana yang dilakukan untuk tujuan tertentu oleh setiap individu. Keuangan merupakan suatu faktor penghambat yang sering kali ditemukan. Keuangan menjadi suatu kebutuhan hidup agar memperlancar suatu kegiatan. Perihal keuangan panti selalu ada pemasukan setiap harinya dari donatur-donatur. Tidak hanya pada keuangan saja, donatur tersebut memberikan sandang, pangan, serta perabotan rumah tangga kepada panti asuhan.

2. Keterlibatan pengurus panti yang maksimal

Keterlibatan pengurus secara maksimal menjadikan suatu strategi agar terorganisir dan dapat menghasilkan tujuan dari suatu suatu program kegiatan. Pengurus panti asuhan putri Muhammadiyah Kota Probolinggo mengabdi secara sungguh-sungguh yang sudah menganggap anak sendiri, dan berprinsip mengasuh sampai kiamat karena Allah.

3. Fasilitas sarana dan prasarana

Menurut Janatusurur (2016:12), fasilitas sarana dan prasarana menjadi sesuatu yang penting dala keberlangsungan proses belajar. Panti asuhan putri Muhammadiyah Kota Probolinggo memberikan fasilitas sarana dan prasarana yang terbaik kepada anak. Terdapat komputer, sound, ruang kegiatan anak, ruang makan, dapur yang luas, kamar tidur yang besar yakni terdapat empat kamar tidur, serta kamar mandi yang bersih.

4. Kegiatan anak

Kegiatan anak tersebut misalnya 
kegiatan pengajian-pengajian, kajian ahad pagi, kajian aisyiyah, al-hadist, tamyiz, qiro'ah, tafsir Alqur'an, kajian aisiyah, hafalan surat Alqur'an, bahasa arab. Serta kegiatan mandiri yakni membersihkan ruangan, belajar bersama, dan kreativitas pembuatan kripik dan seblak.

Begitu pula berdasarkan hasil data yang telah diperoleh mengungkapkan bahwa faktor penghambat peranan peranan panti asuhan putri Muhammadiyah Kota Probolinggo dalam menumbuhkan nilainilai karakter yakni sebagai berikut :

a. Sumber daya manusia minim

Sumber daya manusia yang kompeten sangat diperlukan agar terciptanya sekolah yang berprestasi, unggul, maju sesuai dengan tujuan panti asuhan Muhammadiyah Kota Probolinggo.

b. Karakter anak

Karakter anak asuh panti asuhan putri Muhammadiyah Kota Probolinggo yakni berbeda-beda. Terdapat anak yang susah untuk diatur, susah dinasehati, manja, malu-malu, dan tidak percaya diri. Sehingga membuat pengasuh mendapati kesulitan dalam menghadapi anak asuh

c. Anak pernah pulang malam

Hal ini terjadi ketika anak asuh sedang melakukan kegiatan lain di luar panti tetapi tidak izin kepada pihak panti, sehingga hal tersebut tidak diketahui oleh pihak panti. Akhirnya warga sekitar yang melaporkan kejadian tersebut.

d. Kesenjangan

Terkait kesenjangan dalam hal ini dikarenakan pengasuhnya sepuh jadi tidak maksimal dalam membina dan mendidik anak.

e. Keadaan anak

Keadaan anak yakni keadaan anak yang dengan sakit, capek sehingga tidak bisa mengikuti kegiatan yang ada di panti secara keseluruhan.

f. Kegiatan lain di luar panti

Kegiatan lain di luar panti yakni kegiatan tambahan di luar panti asuhan yakni tapak suci yang ada di sekolah serta anak asuh diikutkan dalam lomba yang mengharuskan berlatih setiap hari sehingga meninggalkan kegiatan yang ada di panti.

\section{Solusi mengatasi hambatan yang} muncul dalam pelaksanaan peranan Panti Asuhan Putri Muhammadiyah Kota Probolinggo dalam menumbuhkan nilai-nilai karakter

Berdasarkan hasil data yang diperoleh sejauh ini solusi yang diberikan oleh pimpinan daerah Muhammadiyah Kota Probolinggo, kepala panti asuhan, pengasuh, dan anak asuh untuk mengatasi hambatan yang muncul yaitu :

a. Meminimalisir segala bentuk hambatan Meminimalisir merupakan suatu usaha dalam mengurangi suatu hambatan yang terjadi. Hal ini menunjukkan minimnya sumber daya manusia yang memiliki jiwa mengasuh. Sehingga supaya panti asuhan maju itu diperlukan adanya sumber daya manusia yang berkompeten dalam bidang mengasuh.

b. Selalu sabar

Menurut Rahayu (2010:16), sabar adalah suatu bentuk kelapangan hati dimana dalam menghadapi sesuatu yang berat, pahit, sulit, keras harus dihadapi dan diterima dengan penuh tanggung jawab. Anak asuh di panti asuhan putri Muhammadiyah Kota Probolinggo memiliki karakter yang berbeda. Sebagai orangtua yang memiliki tanggungjawab untuk membimbing anak harus memiliki ketabahan hati.

c. Pembinaan

Pembinaan merupakan kegiatan mempertahankan dan menyempurnakan apa yang telah ada. Pembinaan 
mempunyai tujuan untuk mendidik yaitu membimbing anak untuk mencapai kedewasaan (Novarisa, 2014:17). Tujuan pembinaan di panti asuhan putri Muhammadiyah Kota Probolinggo agar anak asuh menjadi pribadi dan memiliki karakter yang baik, karena panti asuhan memiliki tanggungjawab untuk membimbing dan membina anak asuh.

d. Memotivasi anak

Menurut Widia (2012:8), motivasi merupakan suatu dorongan yang mampu merubah tingkah laku manusia atau individu dan dapat memicu timbulnya rasa semangat untuk menuju pada hal yang lebih baik. Panti asuhan putri Muhammadiyah Probolinggo selalu memotivasi anak sehingga anak memiliki dorongan dalam diri serta semangat dalam melakukan segala sesuatu, karena dari motivasi tersebut menjadi hal penentu keberhasilan seorang anak.

e. Bertatap muka

Bertatap muka merupakan suatu hubungan komunikasi yang terjalin diantara dua orang bahkan lebih. Bertatap muka dalam panti asuhan putri Muhammadiyah Kota Probolinggo menjadi suatu yang penting karena bertujuan untuk mengetahui terhadap masalah yang terjadi sehingga tidak terjadi miss komunikasi.

f. Diistiqomahkan

Menurut Budi (2014:8), istiqomah adalah keadaan tidak goncang dalam menghadapi berbagai macam problema yang dihadapi dalam kehidupann dengan tetap berpegang teguh pada ajaran Allah SWT dan Rosulullah. Menghadapi hambatan yang terjadi panti asuhan putri Muhammadiyah Kota Probolinggo selalu istiqomah agar mengurangi hambatan yang terjadi. Karena hal itu merupakan jalan pertama yang harus dilalui dalam mencapai suatu tujuan.

\section{SIMPULAN}

Berdasarkan penelitian tentang peranan panti asuhan putri Muhammadiyah Kota Probolinggo, dapat disimpulkan sebagai berikut :

1. Peranan panti asuhan putri Muhammadiyah Kota Probolinggo dalam menumbuhkan nilai-nilai karakter, berprinsip pada rujukan, pedoman, dan acuan yang bertujuan agar terciptanya pembangunan peradaban bangsa yang lebih baik. Panti asuhan membimbing anak setiap hari seperti selalu di nasehati, mewajibkan anak untuk melaksanakan sholat wajib berjamaah dan membaca alqur'an, selalu membimbing anak agar selalu bersifat baik kepada orang-orang yang disekitarnya, saling berbagi, hidup rukun dan damai, mencintai lingkungan, dan dibekali ilmu pengetahuan seperti al-hadist, tamyiz, qiro'ah, tafsir Alqur'an, kajian aisiyah, hafala surat Alqur'an, bahasa arab. Anak diberikan pelayanan fasilitas sarana dan prasarana komputer, sound, ruang kegiatan anak, ruang makan, dapur yang luas, kamar tidur yang besar yakni terdapat empat kamar tidur, serta kamar mandi yang bersih. Terkait pendidikan, anak asuh panti asuhan putri Muhammadiyah Kota Probolinggo diberikan pendidikan di sekolah agar mereka mampu mengejar apa yang diinginkan dan dicapai. Anak asuh juga dibekali kreatifitas yakni pembuatan kripik dan seblak yang bertujuan agar anak memiliki jiwa kewirausahaan

2. Faktor pendudukung peranan panti asuhan putri Muhammadiyah Kota Probolinggo dalam menumbuhkan nilai-nilai karakter yakni: keuangan panti keterlibatan pengurus panti yang maksimal, fasilitas sarana dan prasarana, kegiatan anak. Begitu 
pula faktor penghambat peranan panti asuhan putri Muhammadiyah Kota Probolinggo dalam menumbuhkan nilai-nilai karakter yakni: sumber daya manusia minim, karakter anak, anak pernah pulang malam, kesenjangan karena pengasuhnya sepuh sehingga tidak maksimal, keadaan anak yakni keadaan anak yang sakit dan capek sehingga tidak bisa mengikuti kegiatan secara keseluruhan, dan kegiatan lain diluar panti

3. Solusi mengatasi hambatan yang muncul dalam pelaksanaan peranan panti asuhan putri Muhammadiyah Kota Probolinggo dalam menumbuhkan nilaiyang diberikan oleh pimpinan daerah Muhammadiyah Kota Probolinggo, kepala panti asuhan, pengasuh, dan anak asuh yaitu, (1) meminimalisir segala bentuk hambatan ; (2) selalu sabar menghadapi anak yang berbeda karakter; (3) pembinaan agar anak asuh; (4) memotivasi anak; (5) bertatap muka; (6) diistiqomahkan agar mengurangi hambatan yang terjadi.

\section{DAFTAR PUSTAKA}

Budi, Arid Stiyo. 2014. Dinamika Psikologis Istiqomah Pada Santrihamilil Qur'an Pondok Pesantren Madrasatul Qur'an Tebu Ireng. Malang: Universitas Islam Negeri Maulana Malik Ibrahim Malang, (Online), (http://etheses. uin-malang.ac.id/1631/6/10410065 Bab_2.pdf), diakses 1 Maret 2019.

Hendriana, Evinna Cinda, dan Jacobus, Arnold. 2016. Implementasi Pendidikan Karakter Di Sekolah Melalui Keteladanan Dan Pembiasaan. Jurnal Pendidikan Dasar Indonesia, (Online), 1(2): 25-29, (http:// semnastafis.unimed.ac.id/wp-content/ uploads/2017/11/27.-Nanda-AyuSetiawati.pdf), diakses 2 Februari 2019.
Janatusurur, Rizkita. 2016. Pengaruh Sarana dan Prasarana Belajar Terhadap Hasil Belajar Siswa. Bandung: Universitas Pasundan, (Online), (http://repository. unpas.ac.id/12496/5/BAB\%20II.pdf), diakses 15 April 2019.

Listiowati, Mustika. 2013. Pengaruh Kinerja Keuangan terhadap Harga Saham Perusahaan pada Sektor Perbankan yang Terdaftar Di Bursa Efek Indonesia Periode 2008-2012. Bandung: Universitas Widyatama, (Online),(https://repository. widyatama.ac.id/xmlui/bitstream/ handle/123456789/2857/Bab\%202. pdf? sequence $=6$

Maibang, Suci, Wahyuninta. 2017. Peran Panti Asuhan Puteri 'Aisyiyah Dalam Mengembangkan Kreativitas Anak, (Online), (http://repository.uinsu. ac.id/3165/1/SKRIPSI\%20SUCI\%20 PDF.pdf) diakses 2 Februari 2019.

Moleong, L.J. 2014. Metodologi Penelitian Kualitatif Edisi Revisi. Bandung: PT. Remaja Rosdakarya.

Novarisa, Kinasih. 2014. Pola Pembinaan Di Panti Asuhan Rumah Yatim Arrahman Sleman Yogyakarta. Yogyakarta: Universitas Negeri Jogyakarta, (Online), (https://eprints. uny.ac.id/26950/1/kinasih $\% 20$ novarisa_10102244005.pdf), diakses 1 Maret 2019.

Rayahu, Dwi. 2010. Sabar Sebagai Model Perilaku Dalam Menghadapi Musibah (Suatu Analisis Pada Pemikiran Tm. Hasbi Ash-Shiddiqie). Semarang: Institut Agama Islam Negeri Walisongo, (Online), (http://eprints. walisongo.ac.id/2915/3/1103027 Bab\%202.pdf), diakses 1 Maret 2019. Sobri, Ahmad Yusuf. 2017. Menumbuhkan Nilai Karakter di Sekolah, (Online), (http://ap.fip.um.ac.id/wp-content/ uploads/2015/10/1-ahmad-yusufsobri.pdf), diakses 25 Februari 2019. 
Soekanto, Soerjono. 2015. Sosiologi Suatu Pengantar. Jakarta: Rajawali Press.

Sukmadinata, Nana Syaodih. 2008. Metode Penelitian Pendidikan. Bandung: PT Remaja Rosdakarya.

Suyadi. 2013. Strategi Pembelajaran Pendidikan Karakter. Jakarta: PT. Remaja Rosdakarya Offset.

Widya, Narulita. 2012. Penggunaan Metode College Ball Dalam Upaya Meningkatkan Motivasi Belajar IPS Kelas VIII B SMP N 1 Reban Batang. Yogyakarta: Universitas Negeri Yogyakarta, (Online), (https:// eprints.uny.ac.id/8654/3/BAB\%20 2\%20-\%2008416241010.pdf), diakses 1 Maret 2019.
Peraturan Menteri Pendidikan dan Kebudayaan Republik Indonesia Nomor 20 Tahun 2018 tentang Penguatan Pendidikan Karakter Pada Satuan Pendidikan Formal.

Peraturan Menteri Sosial Republik Indonesia Nomor: 106/Huk/2009 Tahun 2009 pasal 28 Tentang Organisasi Dan Tata Kerja Panti Sosial Di Lingkungan Departemen Sosial.

Undang-Undang Dasar Republik Indonesia Tahun 1945.

Undang-Undang Republik Indonesia Nomor 20 tahun 2003 tentang Sistem Pendidikan Nasional. 